\title{
The Shape of Things to Come
}

\author{
WHICH KEY TRENDS WILL INFLUENCE WEALTH MANAGEMENT IN 3-5 YEARS?
}

By Ed McCarthy

The practice of private wealth management continues to change as quickly as it grows. For insight on key business trends that will influence wealth management over the next three to five years, CFA Institute Magazine invited three experts to share their views in a roundtable discussion: Stephen Horan, CFA, CIPM, managing director of credentialing at CFA Institute; Mark Tibergien, CEO and managing director at Pershing Advisor Solutions, LLC (a BNY Mellon company); and Scott Welch, chief investment

A changing client base driven by demographic shifts will pose challenges for managers, who tend to have different characteristics from the clients they serve.

Wealth managers must deal with an acute talent shortage and difficulty attracting new talent.

Fluctuating prices and margins, combined with the "democratization" of investment solutions/products, will transform the industry. officer at Dynasty Financial Partners. The following excerpts were taken from the participants' remarks. A subsequent column will discuss the impact of technology trends.

\section{THE IMPACT OF WOMEN AND MILLENNIALS}

Stephen Horan (CFA Institute): One thing that I think is getting some more recognition but is largely unnoticed is the increasing significance of women as clientele. Right now, women control about half of the wealth in the US, but they're estimated to be in control of two-thirds of the wealth by 2020. That's stunning. The reasons for that are they're inheriting wealth, they're entering the work force at a greater rate, and they have a greater longevity, so they hang on to that wealth and as a result have longer retirements. Women also tend to be better savers than men. So you've got this changing face of the investor base along the lines of gender, and I think any adviser would tell you advising a woman is very different from advising a man, which is different from advising a couple.

We've spent so much time focusing on retirees and retirement needs that we've sort of taken our eye off the ball that there is an up-and-coming millennial investor base that is becoming increasingly significant in terms of numbers. It's not so much about wealth yet, because they have yet to accumulate significant wealth, but they're partly at the core of this robo-adviser movement. And what's interesting about them (beyond their obvious penchant for digital solutions) is that they disintermediate investment planning. By that I mean you don't really need an adviser to do all the things that they currently do; [investors] can interact more directly with financial markets.

But millennials are also just very different types of investors; they are far more cautious and risk averse than prior generations. For example, they hold about half their sav-

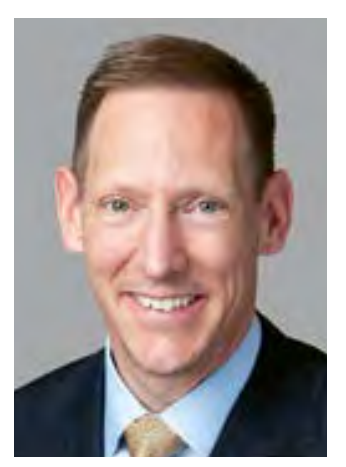

Stephen Horan, CFA, CIPM ings in cash, compared with less than a quarter for all other age groups. They hold more than twice as much cash.

What's interesting about these things taken together is that we have an investor base that increasingly looks less and less like the adviser base, which is middle-aged men-and that perhaps could be generous on the age side [for the adviser base]. That's going to continue to create challenges for advisers who are trying to serve clients who don't share the same perspectives and life experiences, [who have a] penchant for digital solutions and things like that.

\section{TALENT SHORTAGE}

Mark Tibergien (Pershing Advisor Solutions): There is an acute talent shortage facing all the financial services. Since 2008, there are 50,000 fewer financial professionals in all. I think the average age for principals is around 61, but the average age for all advisers is about 50 . Only $10 \%$ of the adviser population is under the age of 35 . In fact, the CFP Board [Certified Financial Planner Board of Standards, Inc.] says they have more CFPs over the age of 70 than they do under the age of 30 .

Whatever you use as your data point, the face of the advisory business is gray and wrinkled, and that is a challenge because we as an industry have not done a good job of making this a compelling industry to work in. We [Pershing Advisor Solutions] asked our Millennial Advisory Board to casually inquire among their friends who are not in this business why they chose not to come into finance. There were three reasons cited: (1) I never studied it in high school and didn't know it was a career choice; (2) everything I know about the industry is bad; it's corrupt; it's not a place that profoundly helps the lives of other people; and (3) it's just a sales job, and I don't want to be in sales. So, as a profession, we have a lot of work to do to demonstrate that it's actually a helpful career; it's not a sales job. If people are not learning personal economics in high school, that probably explains why people make a lot of bad financial decisions. 


\section{FLUCTUATING PRICES AND MARGINS}

Mark Tibergien (Pershing Advisor Solutions): This is the only profession where clients pay for the value they bring rather than the value the professional brings-meaning that, the richer I am, the more that I pay. It's kind of a classic Marxist sort of approach to pricing when you think about it.

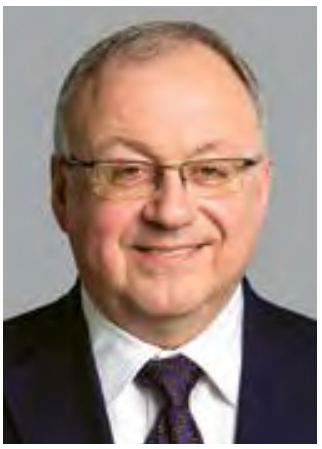

Mark Tibergien What's happening is that firms do continue to charge basis points on assets, but in many cases, they're also charging a retainer or a project fee for other services. But it's not uncommon in the high-net-worth space to actually see a 5-10 basispoint increase in the asset management fee.

There are six levers of profitability in a wealth management firm. Pricing is one of them and perhaps the most controllable, but the others relate to volume, meaning that many firms are not growing at a rate fast enough to keep up with withdrawals. Productivity is becoming a real issue, because [firms are] not managing workflow well, and that's a function of capacity. Third, the service mix may not be well defined, and one reason it's not well defined is because of the fourth lever, a poor client mix, where the firms don't have enough clients within their sweet spot. The fifth lever relates to cost control. Finally, bull markets camouflage a lot of sins, and in some respects, we've seen this persistent growth in the equity markets, which has allowed for creeper costs to come into a number of advisory firms. If you look at those six levers [pricing, productivity, service mix, client mix, cost control, and creeper costs], you have to say it isn't just pricing that determines my margins; it's "How do I manage the rest of the ship in order to produce an optimal bottom line?"

\section{EVOLVING INVESTMENT MANAGEMENT}

Scott Welch (Dynasty Financial Partners): One trend on the investment side is the democratization of the investment solution set that's available to clients. A second is simply what I call the "race to zero" in terms of active asset management fees.

One aspect of the democratization trend is the explosion in the number of liquid alternatives, or alternative investment mutual funds, that are now available. Both the quantity and quality of those strategies continue to improve, and that will make accessible to a wider audience of investors the kinds of strategies that historically have only been available to qualified purchasers or accredited investors.

This is not to suggest, by the way, that hedge funds or LPs (limited partnerships) are doomed for the graveyard. I think the good ones will continue to thrive and prosper. But the door is now open to a much wider set of investors to build far more diversified and sophisticated portfolios beyond simply stocks and bonds.

A second trend is the explosion of exchange-traded funds (ETFs), so-called factor-based ETFs, and other low-cost structures now available to investors. I don't like the phrase "smart beta," but that is the industry shorthand for factor-based ETFs.

As a simple example, Eaton Vance got approval not too long ago for a new kind of structure called an ETMF (exchangetraded mutual fund), which is an actively managed ETF. It has the daily liquidity of an ETF, but the fund company doesn't have to disclose the underlying positions within that ETF on a daily basis like it does with a traditional ETF. Its disclosure is based more on the mutual fund standard of every six months, which will allow that ETF provider to more actively manage the strategy without daily transparency into it. I don't know if it will be a good product or a bad product, but I do know it will work to drive down the price of active management.

When you combine all the different lower-cost investment products that have and will continue to come out, I think it's undeniable that there will be a deep impact on active managers. Premium managers will always be able to charge a premium price, but many active managers are going to have to change the way that they manage their books in order to justify their higher fees. That's why I refer to this

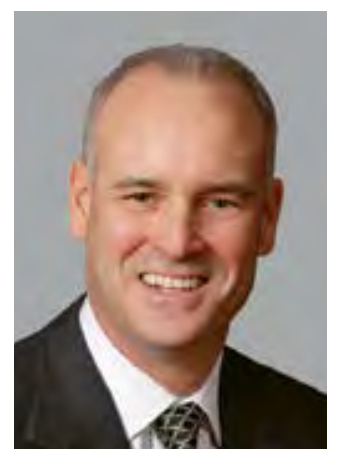

Scott Welch trend as the race to zero, and it's happening both at the product level and at the advisory level because of digital platforms.

I think we will see a similar impact in the LP and hedge fund space in the sense that the truly brilliant investors will survive and thrive, and they'll continue to be able to charge premium prices for premium performance. Clients will still be willing to give up liquidity and pay a higher fee in order to get access to that performance. So, I suspect that "star managers" and things like private equity and other illiquid investments will continue to be very popular. But these pricing pressures pose a distinct competitive threat for the folks who aren't premium providers.

The bottom line from an investment perspective is that an end investor now can build a very sophisticated, very globally diversified portfolio at a far lower cost and with far better liquidity terms than that same client could have built even five years ago. Asset managers and wealth managers are going to have to respond to all of these trends. In an era of commoditization of services, they will need a differentiated business model and clear articulation of their value proposition to justify their

\section{KEEP GOING}

"Toward a New Framework for Private Wealth," CFA Institute Magazine (January/February 2015) [www.cfapubs.org]

"Sharing the Wealth: Does giving ownership equity to employees help firms?" CFA Institute Magazine (July/August 2015) [www.cfapubs.org] higher fees. And in the wake of downward pricing pressure, they will need to focus on core competencies and increase their use of outsourcing to drive profitability.

Ed McCarthy is a freelance finance writer in Pascoag, Rhode Island. 